\title{
A regionális tudomány a változó világban Megjegyzések Lengyel Imre tanulmányához
}

\section{Regional science in the changing world Comments on Imre Lengyel's article}

\author{
MÉSZÁROS REZSŐ
}

A 80. születésnapját ünneplő Enyedi György akadémikus tiszteletére érdekes, gondolatébresztó tanulmányt jelentetett meg Lengyel Imre professzor a Tér és Társadalom 2010. 3. (11-40.) számában a regionális tudomány előtt álló legfontosabb kihívásokról és a lehetséges válaszokról. Minden ilyen jellegü munka nagyon szükséges, de rendkívül merész vállalkozás is, mégis jó, hogy az írás elkészült, van vitaalap. Jó lenne, ha széles szakmai eszmecsere kerekedne.

Mentegetni szeretném magam, nem az egész tanulmányhoz füzök megjegyzéseket, hanem csak néhány vonásáról, kiragadott tartalmi egységéről. Azzal kezdem, hogy ez az információgazdag dolgozat bizony nem könnyű olvasmány. Túlságosan sok témát érint, ráadásul oly sok mindenkire hivatkozik, hogy az már szinte szétszabdalja a mondanivalót. De bőven kavarognak benne optimista és pesszimista hangulatok is, amelyek fölösleges aggodalommá erősödnek némely helyen. Azért ez még nem a vég kezdete, sőt még az sem biztos, hogy ez a kezdet vége. Hiszen a hazai regionális tudomány a teljesítménye alapján a magyar és nemzetközi tudományosság részévé vált. Ezzel indította tanulmányát a szerző is. Ezt a tényt azoknak is el kellene ismerni, akik a regionális tudománnyal szemben fenntartásokkal vagy barátságtalan érzelmekkel viseltetnek.

A regionális tudomány hazai és nemzetközi gondjai, feszültségei többnyire azonosak a tudományterület szintjén. De egészen sajátos a hazai jelenlegi állapot: a finanszírozás lehetetlenségei, a regionális tudomány akadémiai helyzete, a társtudományokkal való kapcsolatrendszerének alakulása. Ezért a tanulmány címében felvetett jövőkép, a „térnyerés” nem reális, attól tartok, tényleg "csalfa délibáb” - ha jól értem a címet. Talán a magyarországi regionális tudomány biztonságos jövőképe, legalábbis középtávon, az eddig elért pozíciók visszaszerzése és stabilizálása lehet. Miközben néhány régebbi és újabb elméleti, tematikai és módszertani kérdés, kihívás folyamatos szorításában kellene a megújulást keresni - Enyedi György kifejezésével élve - abból a

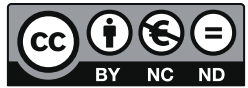


tudáskészletből is merítve, amivel a hazai és nemzetközi regionális tudomány folyamatosan felhalmoz. De, azt hiszem, elsősorban rendkívül fontos, mondhatni továbbra is alapkövetelmény, hogy a hazai regionális tudomány meg tudja őrizni önálló arcát.

Tudom, hogy a regionális tudomány nyitott, befogadó tudomány, hovatovább ez a regionális tudomány egyik meghatározó jellemzője. Úgy tűnik azonban, hogy a hazai regionális tudományban most mintha nehezítené a gyorsabb előrelépést, hogy egymás mellett (talán túl erősen is) jelen van társadalmi és a gazdasági térszemlélet, sőt a kettő egyfajta keveréke is. Ráadásul még más tudományterület művelőit is szívesen látják, akiknek szemléletében vagy kutatási koncepciójában kiemelt helyet foglal el a tér, ami nem is lenne kifogásolható, de Lengyel Imre egy 2003-ban írt Nemes Nagy József-tanulmányból idéz („a társadalmi térelméleti kutatások nem háríthatók át semmilyen más tudományágra, ebben magáé a regionális tudományé a fő felelősség"), amivel egyetért. Nem volt meglepő, ezt a „határozott” megállapítást már a megjelenésekor, különösen a társadalomföldrajzot művelő geográfusok közül sokan bírálták. A térszemléleti sokszínüség persze jó is lehet, bár a bemutatott helyzetértékelés kétségeket támaszt, mert egyrészt belső törésvonalak kialakulásának veszélyét hordozza, másrészt nehézséget okozhat a más tudományágakkal való együttmüködésben. Ezzel kapcsolatban érdemes figyelemmel lenni arra, hogy a regionális tudomány, valamint a társadalomföldrajz számára - talán a közel azonos globális és regionális kihívások kapcsán is - meglehetősen sok közös találkozási felület van. De ez a körülmény nem lehet ok az összefeszülésre, hanem inkább arra, hogy ne egymás torkát, hanem egymás kezét keressük. Az együttmüködésre számos jó példa van.

Lengyel Imre kiemelt figyelmet, pontosabban nagy fontosságot tulajdonít a regionális tudományban is a földrajzi távolsághoz kapcsolódó összefüggéseknek, különös tekintettel a „földrajzi távolság halálára”. Sajátos, de érdekes feldolgozást mutat be, valójában két fejezetben (szorosan kapcsolódik ide az „Oly távol vagy tőlem..." fejezet is). A téma sokféle megközelítési lehetőséget kínál, én némileg más megoldást választok, mint a szerző, de talán nem távolodok el nagyon.

Ismert, hogy a 20. század második felében, de még inkább az utolsó harmadában, az információs és kommunikációs technológiák gyors fejlődése számos alapvető globális és regionális gazdasági, társadalmi új folyamatot indított el, amelynek térbeli következményei is vannak, ami ismét felvetette a távolság halála gondolatát, már csak egyszerű tapasztalati okok alapján is. Ez a folyamat azonban többrétü. Egyrészt az általánosítás szintjén a hely-tér-idő változó viszonyrendszerének kérdéskörébe tartozik, és filozófiai tartalmat takar. Másrészt viszont a közgazdaság-tudományi, regionális tudományi, társadalom-földrajzi stb. gondolkodásban többnyire az elérhetőség problémaköreként is megjelenik, amelynek változásával többnyire átalakul a térszemlélet is. Kétségtelen, hogy a távolság halála és az elérhetőség egyre növekvő szerepe az ember napi cselekvésében is kimutatható. Sőt, ha történelmileg nézzük, a kérdés 
gyökeréhez juthatunk közel, pedig akkor még nem is volt információs és kommunikációs technológiai forradalom, de már akkor is volt az emberben fékezhetetlen kíváncsiság, veleszületett tudásvágy. Például az, hogy miképpen tudja minél gyorsabban legyőzni a teret? A történet tehát nagyon régen, az ókorban kezdődhetett, először hang, majd fényüzenetekkel közöltek híreket, vagy a harci cselekményekben alkalmazták. Tehát már az ókorban is képes volt az ember bizonyos térméretben, korlátozott eszközökkel, tartalommal és időkeretben legyőzni a teret a neki szükséges célból.

Később is ez maradt az alapkérdés: hogyan tudja az idő egyre jobban (egyre sebesebben) legyőzni a teret, aminek eredménye lett a távolság átértékelődése (nem feltétlenül a brazil őserdőben, hanem globális, regionális, de még lokális szinteken is). De miért is szeretné legyőzni az ember egyre sebesebben a teret? Hogy hamarabb jusson információhoz, termékhez, munkához, irányitsa és uralkodjon a térben történo" események fölött. Ez ugyan magában hordozza a kirekesztés lehetőségét, vagy inkább tényét, de azt hiszem, hogy a tétel igaz voltát nem befolyásolja. Következésképpen ezt az egész kérdéskört sok irányból lehet megközelíteni, különösen annak ismeretében, hogy az információs és kommunikációs technológia fejlődése kölcsönös hatásrendszer alapján megy végbe, amiben a társadalom igénye az idetartozó néhány ágazatban dinamizáló erejü. Ez visszahat az ember kommunikációs viselkedésére, a virtuális világgal kialakuló viszonyára is. Az embernek veleszületett tér- és idoeérzéke van. Az információs és kommunikációs technológiák gyors fejlődése és magas térkínálati szintje hirtelen új helyzetet teremtett, és folyamatos új térkínálati lehetőséget ad az emberiség egyre növekvő része számára. Az emberi tér- és idoérzék nagyfokú és magas szintű alkalmazkodóképességének egyik fontos bizonyítéka az, hogy "gyorsan fel tudta venni ezt a ritmust”, az, hogy olyan gyorsan, nagy számban elterjedt a mobiltelefon, a számítógép, a GPS stb. Amikor Lengyel Imre arról ír, hogy „napjainkban ezek a kihívások főleg a globalizációs folyamatok térbeli hatásaihoz, a digitális kommunikáció elterjedéséhez köthetők, amelynek következményeként egyre erőteljesebben érzékelhető a regionális tudomány térszemléletének megújulási igénye is" (Lengyel 2010, 3-11.), igaza van, de ez egyben még egy adalék a térrel kapcsolatos fentebbi megjegyzéshez.

Miután a szerző nem említi, szükségesnek tartom megjegyezni, hogy az idő-tér-problémát vizsgáló megnevezések közül azért lett a "távolság halála” a leginkább kedvelt formulává, mert ezzel a címmel írt feltűnést keltő cikket a „The Economist” 1995. szeptember 30-i számában Frances Cairncross. És éppen ebben az írásban teszi felelőssé a telekommunikáció fejlődését a földrajz elhalásáért a globális információtranszfer korában. Remélhetőleg még nem jött el az ideje annak, hogy földrajz halottnak nyilváníttassék. Feltehetően még csak nem is haldoklik, de az gyakran megtörténik (megtörtént a múltban is), hogy a társadalomföldrajz, érzékelve a gazdaságban, a társadalomban végbemenő változásokat, igyekszik újabb és újabb megközelítésekkel alkalmasnak mutatkozni arra, hogy e változások belső és térbéli összefüggéseit elemezze és értelmezze. 
Végül is Lengyel Imre ugyanezt teszi, amikor töpreng a regionális tudomány sorsa fölött. De ugyanezt tette a „The Economist” tárcaírója is a lap 2003. március 15-i számában. Az írás címe: „A földrajz bosszúja”. A szerző kifejtette, hogy naiv gondolat volt azt hinni, hogy a földrajzot jelentéktelenné teszi az internet globális terjedése. Az internet felvirágzásának korai időszakában sokat beszéltek a „távolság haláláról”. Úgy tűnt, hogy a globális digitális hálózat véget vet a földi fizikai vagy a földi földrajzi kényszernek. Volt ebben némi igazság. Valójában azonban a földrajz egyáltalán nem halott. Gyakran segít, ha az internetre gondolunk, hogy használói a való világban élnek, ahol a földrajz határai még léteznek, ezek a határok online terjeszkednek, de nem könnyü megtalálni egy bizonyos helyhez vagy információhoz való kötődésüket. Ma már lényeges haladás történ ezen a területen, és a hely jelentősége felértékelődött. Tehát abban az összetett viszonyrendszerben, amely az idő-tér-problémakörből indítható, visszajuthatunk a helyig, ha úgy tetszik a lokalitásig, vagy még inkább a kiindulásig. A földrajzi dimenzió bizonyos esetekben új értelmezést kap. Gál Zoltán kitűnő könyvének bevezetésében két mottó szerepel. Az egyik egy Richard O’Brien-idézet (1992), amelyik pontosan ideillik: „A földrajzi hely továbbra is létezik, még ha az elektronikus piacok világában nehezebb is azt meghatározni a hagyományos földrajzi módszerekkel. A pénzügyi vállalatoknak, egyéneknek, piacoknak, de még az egyes termékeknek is van lokális tudata" (Gál 2010, 11.).

$\mathrm{Az}$ internet lehetőséget teremtett olyan formák, működési mechanizmusok kialakulásához, amelyek a hely szerepét tovább erősítették, ilyenek például az e-kereskedelem különböző típusai, vagy az a tény, hogy a helyi piacokról való ismeretek egyre inkább a vállalati stratégiák alapelemévé válnak. Az internet, a műholdak, a mobilkommunikáció a helymeghatározás újabb és újabb formáit teremtik meg. A nemzetközi terrorizmusban a hely szerepe egyre magasabb technológiai szinten realizálódik. A regionális háborúkban egyre inkább meghatározó szerepet játszik a kiberháború-forma, amelyben a hely a célpont (R. A. Clarke, R. Knake 2010). Megjegyzem, hogy az Amerikai Egyesült Államok a közelmúltban hozott létre nagy létszámú szakértőgárdát, „hadsereget" az ország kiberterének védelmére. A egész kérdéskör tehát egy újabb dimenzióban jelent meg napjainkban.

\section{Irodalom}

Cairncross, F. (1995): The Death of Distance. The Economist, 30th September, 336.

Clarke, R. A., Knake, R. (2010): Cyber War. HarperCollins Publishers

Gál Z. (2010): Pénzügyi piacok a globális térben. Akadémiai Kiadó, Budapest

Lengyel I. (2010): A regionális tudomány „térnyerése”: reális esélyek avagy csalfa délibábok?

Tér és Társadalom, 3., 11-40.

The Economist (2003): The Revenge of Geography. 15th March, 22-27. 


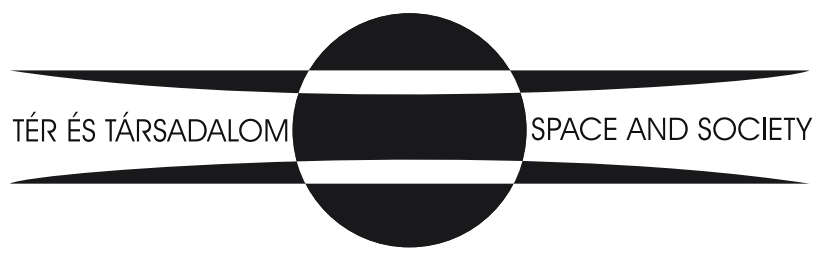

